\title{
DYNAMIC MODEL OF SPEED CONTROL THROUGH RING GEARS IN A DEVICE WITH A MULTISTAGE GEAR DIFFERENTIALS AND CLOSED-LOOP HYDRAULIC SYSTEMS
}

\author{
Oleh Strilets
}

\author{
National University of Water and Environmental Engineering, Rivne, Ukraine
}

\begin{abstract}
Summary. The dynamic processes in the device for speed control with multistage gear differential and closed-loop hydraulic systems through ring gears have been studied for case when the leading link is the sun gear of the first stage, and the driven is a carrier of the last stage. For such a device, the equation of kinetic energy has been compiled and the dynamics equations have been obtained by the Lagrange method, which have been solved. The obtained results are the basis for further computer simulation on and quantitative analysis to assess the performance of such devices and select the necessary closed-loop hydraulic systems to control speed changes.

Key words: dynamic model, speed control device, gear differential, closed-loop hydraulic system, sun gear, ring gear, carrier, planet.
\end{abstract}

Problem statement. In the drives of hoisting and transport, building, road, land reclamation, agricultural and mining machines, cars and tractors, ships, aircraft and submarines, there is a need to control changes in speed in the magnitude and direction of their actuators. For this purpose, devices with stepped and stepless speed control are often used by means of stepped and stepless gearboxes, which have simple and complex gear boxes, or chain, belt and friction variators. The main disadvantages of the existing stepped speed control are the complexity of the design, high material consumption, complexity of automation, the emergence of dynamic loads during transitions from one speed to another. Flows of traditional stepless gear boxes intensive operation of parts due to the use of friction joints, like belt or disk brakes or friction couplings. This significantly reduces the durability and reliability of drive parts and machinery in general. Therefore, based on the review and analysis of existing speed change devices, it is concluded [1] that the urgent scientific and technical task is to develop and study new combined devices for stepless control of speed change in the form of multistage gear differentials with closed-loop hydraulic systems through ring gears, which energy efficiency is proved in [2].

Analysis of recent research and publications. Recent studies and publications have been taken into account, in which research has been dedicated to devices with single-stage and multi-stage gear differentials [3-18].

In [3] the influence of the change in the shape of the tooth profile of the planetary gear on the dynamics without considering energy consumption has been analyzed.

In [4], a nonlinear dynamic model of a two-stage planetary mechanism based on an analytical solution of dynamic equations in the MATLAB program has been proposed and investigated, but the losses expressed in efficiency were not considered.

In [5] a joint analysis have been held for the ranges of efficiency and transmission ratio of planetary gears, which can be achieved by all possible design solutions.

In [6] the results of checking the dynamic model of the drive with a gearbox, which have been carried out on a real object in different operating conditions and stimulation studies to determine the suitability of the model, but without taking into account energy efficiency. 
In [7] a new method of calculating kinematic and force parameters based on hypergraph and matrix operation has been suggested. The efficiency has been calculated following the power flow, and the power loss equation at each node has been derived through an approach based on the relative force of the rotation itself.

In [8] the formulas of theoretical efficiency for two-stage differential transmission have been obtained and tested by experimental studies.

In [9] the efficiency of complex gears has been investigated on the basis of graphic and thread theories, which allow to obtain approximate values.

[10] substantiates the reduction of the cost of construction of multi-speed planetary gears based on system synthesis, considering such requirements as the ratio degree, efficiency, planarity of the mechanism and one transient shift, for heavy vehicles.

In [11] the design of a two-planetary gearbox with the calculation of kinematics, statics and gearing efficiency has been presented. Calculations of the geometry and strength of gears, shafts and rolling bearings have been omitted, as they are recognized as typical design calculations.

In [12], based on the torque, equations of force balance and force analysis of the main elements, the power distribution of a multistage microplanetary reducer $2 \mathrm{~K}-\mathrm{H}$ has been analyzed.

In [13], the authors have proposed an algorithm for solving the problem of detecting degenerate planetary gears, automated using an interactive computer program. The algorithm has been used for transmissions with any number of degrees of freedom.

In [14] attention has been paid to a full understanding of the basic mechanics of planetary gears and evaluation of their mechanical efficiency and it has been concluded that for the same input and output links power loss has a unique mathematical expression for each real sequence of angular velocities.

In [15] the reasons which restrain application of smoothly regulated planetary transfer, owing to constructive complexity of the mechanism of regulation of the gear ratio have been resulted and variants of its simplification have been described.

In [16] it has been noted that planetary gears are used in industry for many advantages, which are increased efficiency and a very compact drive composed of gears and failure of one link affects the entire transmission, so you need to know the reasons for this.

In [17], a dynamic model of speed control through a ring gear of a drive with a gear differential transmission and a closed-loop hydraulic system has been proposed - a system of differential equations has been obtained.

In [18], a dynamic model of speed control through a sun gear with a single-stage differential gear and a closed-loop hydraulic system has been proposed - a system of differential equations has been obtained and solved.

In [19], a dynamic model of speed control through a drive carrier with a gear singlestage differential transmission and a closed-loop hydraulic system has been proposed - a system of differential equations has been obtained and solved.

In [20], the determination of the combined torques to the drive link of the device for changing the speed through the gear differential, which can be a ring gear, or a carrier, or a sun gear.

An analysis of recent publications shows that insufficient attention has been paid to the dynamics of new speed control devices with multistage gear differentials using a closed-loop hydraulic system. These issues of the dynamics of such devices are waiting to be resolved. The study of the dynamics of such devices will allow to develop methods to reduce the impact of dynamic loads on them.

The purpose of the study. Develop a mathematical model of dynamic processes in speed change devices using multistage gear differentials with closed-loop hydraulic systems in 
the case where the control links are ring gears, and the drive link is a sun gear of the first stage, and the driven link is the carrier of the last stage.

Implementation of work. Fig. 1 shows a diagram of a multi-stage gear differential, where speed control is performed using closed-loop hydraulic systems and ring gears.

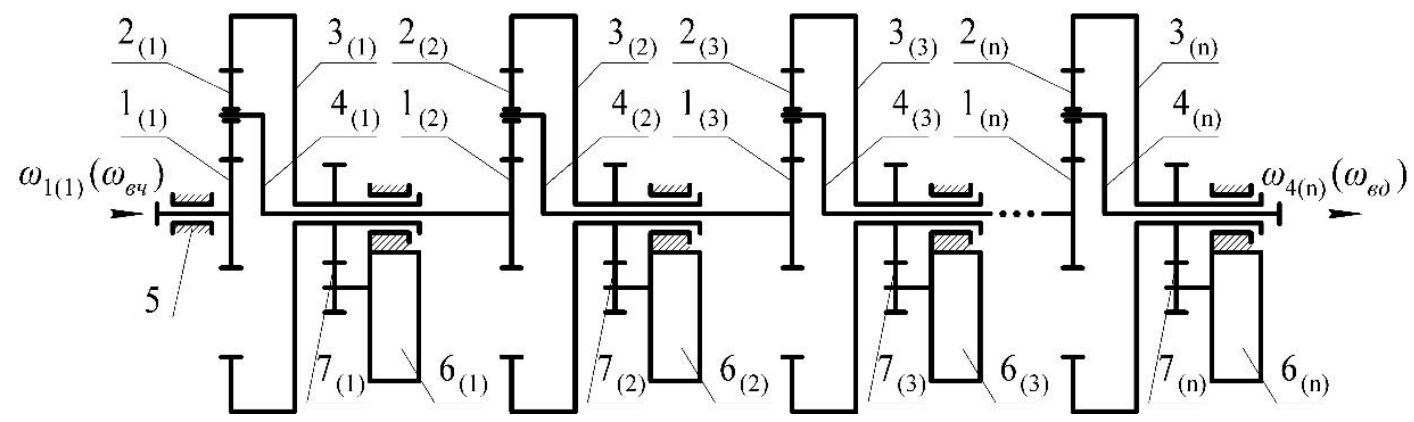

Figure 1. Scheme of multistage gear differential with closed-loop hydraulic systems with speed control through ring gears

In this gear differential, the carrier $4_{(1)}$ of first stage is connected to the second-stage sun gear $1_{(2)}$, the carrier $4_{(2)}$ of second stage is connected to the third-stage sun gear $1_{(3)}$, and so on. Speed control is carried out by ring gears $3_{(1)}$ of the first, $3_{(2)}$ of the second, $3_{(3)}$ of the third, $\ldots, 3_{(n)}$ of $n$-th stages by means of installed on them closed-loop hydraulic systems $6_{(1)}, 6_{(2)}, 6_{(3)}, \ldots, 6_{(n)}$. The leading in such a gear differential is the sun gear $1_{(1)}$ of the first stage, and the driven is the carrier $4_{(n)}$ of the $n$-th stage. Closed-loop hydraulic systems systems $6_{(1)}, 6_{(2)}, 6_{(3)}, \ldots, 6_{(n)}$ are identical in structure, placed in the housing 5 and connected to the ring gears through gearings $7_{(1)}, 7_{(2)}, 7_{(3)}, \ldots, 7_{(n)}$. The speed change is controlled by a control valve, through which the fluid moves in a closed-loop hydraulic system. The structure and operation of a closed-loop hydraulic system is described in detail in [21].

We write the dynamic model of motion of a multistage gear differential with speed control through ring gears in a formalized form, using the Lagrange equation of the second kind

$$
\frac{d}{d t}\left(\frac{\partial T}{\partial \omega}\right)=M_{4(n)}
$$

To do this, we write the expression for the kinetic energy of the system $T$, of the device shown in Fig. 1. The expression for the kinetic energy of the system includes the kinetic energies of the following links: $T_{1(1)}, T_{1(2)}, T_{1(3)}, \ldots, T_{1(n)}-$ sun gears with shafts; $T_{2(1)}, T_{2(2)}, T_{2(3)}, \ldots, T_{2(n)}-$ planet blocks; $T_{3(1)}, T_{3(2)}, T_{3(3)}, \ldots, T_{3(n)}-$ ring gears with paired gears 7 , respectively $7_{(1)}, 7_{(2)}, 7_{(3)}, \ldots, 7_{(n)} ; T_{4(1)}, T_{4(2)}, \mathrm{T}_{4(3)}, \ldots, \mathrm{T}_{4(n)}-$ carriers; $T_{6(1)}, T_{6(2)}, T_{6(3)}, \ldots, T_{6(n)}$ - closed-loop hydraulic systems $\sigma_{(1)}, \sigma_{(2)}, \sigma_{(3)}, \ldots, \sigma_{(n)}$ with gearings, respectively $7_{(1)}^{\prime}, 7_{(2)}^{\prime}, 7_{(3)}^{\prime}, \ldots, 7_{(n)}^{\prime}$

The expression of the kinetic energy of such a system $T$ has the form

$$
\begin{aligned}
& T=\frac{1}{2}\left\{\left[J_{1(1)} \omega_{1(1)}^{2}+z_{c(1)} J_{2(1)} \omega_{2(1)}^{2}+z_{c(1)} m_{2(1)} v_{o(1)}^{2}+\left(J_{3(1)}+J_{7(1)}\right) \omega_{3(1)}^{2}+J_{4(1)} \omega_{4(1)}^{2}+\left(J_{7(1)}^{\prime}+J_{6(1)}\right) \omega_{6(1)}^{2}\right]+\right. \\
& +\left[J_{1(2)} \omega_{1(2)}^{2}+z_{c(2)} J_{2(2)} \omega_{2(2)}^{2}+z_{c(2)} m_{2(2)} v_{o(2)}^{2}+\left(J_{3(2)}+J_{7(2)}\right) \omega_{3(2)}^{2}+J_{4(2)} \omega_{4(2)}^{2}+\left(J_{7(2)}^{\prime}+J_{6(2)}\right) \omega_{6(2)}^{2}\right]+ \\
& +\left[J_{1(3)} \omega_{1(3)}^{2}+z_{c(3)} J_{2(3)} \omega_{2(3)}^{2}+z_{c(3)} m_{2(3)} v_{o 2(3)}^{2}+\left(J_{3(3)}+J_{7(3)}\right) \omega_{3(3)}^{2}+J_{4(3)} \omega_{4(3)}^{2}+\left(J_{7(3)}^{\prime}+J_{6(3)}\right) \omega_{6(3)}^{2}\right]+ \\
& \left.+\ldots+\left[J_{1(n)} \omega_{1(n)}^{2}+z_{c(n)} J_{2(n)} \omega_{2(n)}^{2}+z_{c(n)} m_{2(n)} v_{o 2(n)}^{2}+\left(J_{3(n)}+J_{7(n)}\right) \omega_{3(n)}^{2}+J_{4(n)} \omega_{4(n)}^{2}+\left(J_{7(n)}^{\prime}+J_{6(n)}\right) \omega_{6(n)}^{2}\right]\right\},
\end{aligned}
$$


where: $\omega_{1(i)}, \omega_{2(i)}, \omega_{3(i)}, \omega_{4(i)}, \omega_{6(i)}-$ respectively, the angular velocities of the system; $J_{1(i)}, J_{2(i)}, J_{3(i)}, J_{4(i)}, J_{6(i)}$ - respectively, the dynamic moments of inertia of the links relative to the centers of mass; $m_{2(\mathrm{i})}-$ the mass of the planet block; $z_{c(i)}$ - number of planets; $v_{o 2(i)}=\omega_{4(i)} r_{4(i)}$ - circular speed of the axis of rotation of the planets; $r_{4(i)}$-radius of rotation of the carrier. This radius is equal to the sum of the initial radii of the sun gear and the planet $r_{4(i)}=0,5\left(d_{w 1(i)}+d_{w 2(i)}\right)$, and $i=1,2,3, \ldots, n$.

The angular velocities included in (2) are expressed in terms of the angular velocities of the leading and driven links [22] for all stages:

$$
\begin{gathered}
\omega_{1(1)}-\text { driving link (sun gear); } \omega_{1(2)} ; \omega_{1(3)} ; \ldots, \omega_{1(n)} ; \\
\omega_{2(1)}=\omega_{1(1)} u_{21(1)}^{(4)}+\omega_{4(1)} u_{24(1)}^{(1)} ; \omega_{2(2)} ; \omega_{2(3)} ; \ldots, \omega_{2(n)} ; \\
\omega_{3}=\omega_{1} u_{31}^{(4)}+\omega_{4} u_{34}^{(1)} ; \omega_{3(2)} ; \omega_{3(3)} ; \ldots, \omega_{3(n)} ; \\
\omega_{4(1)} ; \omega_{4(2)} ; \omega_{4(3)}, \ldots, \omega_{4(n)}-\text { driven link (carrier); } \\
\omega_{6(1)}=\frac{\omega_{3(1)}}{u_{7^{\prime} 7(1)}} ; \omega_{6(2)} ; \omega_{6(3)} ; \ldots, \omega_{6(n)} .
\end{gathered}
$$

where the gear ratios for the stages are equal to:

$$
\begin{gathered}
u_{21(1)}^{(4)}=-\frac{z_{1(1)}}{z_{2(1)}} ; u_{21(2)}^{(4)}=-\frac{z_{1(2)}}{z_{2(2)}} ; u_{21(3)}^{(4)}=-\frac{z_{1(3)}}{z_{2(3)}} ; \ldots, u_{21(n)}^{(4)}=-\frac{z_{1(n)}}{z_{2(n)}} ; \\
u_{31(1)}^{(4)}=-\frac{z_{1(1)}}{z_{3(1)}} u_{31(2)}^{(4)}=-\frac{z_{1(2)}}{z_{3(2)}} ; u_{31(3)}^{(4)}=-\frac{z_{1(3)}}{z_{3(3)}} ; \ldots, u_{31(n)}^{(4)}=-\frac{z_{1(n)}}{z_{3(n)}} ; \\
u_{24(1)}^{(1)}=1-u_{21(1)}^{(4)}=1+\frac{z_{1(1)}}{z_{2(1)}} ; u_{24(2)}^{(1)}=1-u_{21(2)}^{(4)}=1+\frac{z_{1(2)}}{z_{2(2)}} ; \\
u_{24(3)}^{(1)}=1-u_{21(3)}^{(4)}=1+\frac{z_{1(3)}}{z_{2(3)}} ; \ldots, u_{24(n)}^{(1)}=1-u_{21(n)}^{(4)}=1+\frac{z_{1(n)}}{z_{2(n)}} ; \\
u_{34(1)}^{(1)}=1-u_{31(1)}^{(4)}=1+\frac{z_{1(1)}}{z_{3(1)}} ; u_{34(2)}^{(1)}=1-u_{31(2)}^{(4)}=1+\frac{z_{1(2)}}{z_{3(2)}} ; \\
u_{34(3)}^{(1)}=1-u_{31(3)}^{(4)}=1+\frac{z_{1(3)}}{z_{3(3)}} ; \ldots, u_{34(n)}^{(1)}=1-u_{31(n)}^{(4)}=1+\frac{z_{1(n)}}{z_{3(n)}} ; \\
u_{7^{\prime}(1)}^{(4)}=-\frac{z_{7^{\prime}(1)}}{z_{7(1)}} ; u_{7^{\prime}(2)}^{(4)}=-\frac{z_{7^{\prime}(2)}}{z_{7(2)}} ; . u_{7^{\prime}(3)}^{(4)}=-\frac{z_{7^{\prime}(3)}}{z_{7(3)}} ; \ldots, u_{7^{\prime} 7(n)}^{(4)}=-\frac{z_{7^{\prime}(n)}}{z_{7(n)}} .
\end{gathered}
$$

We substitute the values of velocities in expression (2), simplify and write in the form:

$$
\begin{gathered}
T=\frac{1}{2} \sum_{i=1}^{i=n}\left\{\left[J_{1(n)}+z_{c(n)} J_{2(n)}\left(u_{21(n)}^{(4)}\right)^{2}+\left(J_{3(n)}+J_{7(n)}+\frac{J_{7(n)}^{\prime}+J_{6(n)}}{u_{77(n)}^{2}}\right)\left(u_{31(n)}^{(4)}\right)^{2}\right] \omega_{1(n)}^{2}\right. \\
+2\left[z_{c(n)} J_{2(n)} u_{24(n)}^{(1)} u_{21(n)}^{(4)}+\left(J_{3(n)}+J_{7(n)}+\frac{J_{7(n)}^{\prime}+J_{6(n)}}{u_{77(n)}^{2}}\right) u_{34(n)}^{(1)} u_{31(n)}^{(4)}\right] \omega_{1(n)} \omega_{4(n)}+ \\
\left.+\left[z_{c(n)} J_{2(n)}\left(u_{24(n)}^{(1)}\right)^{2}+\left(J_{3(n)}+J_{7(n)}+\frac{J_{7(n)}^{\prime}+J_{6(n)}}{u_{77(n)}^{2}}\right)\left(u_{34(n)}^{(1)}\right)^{2}+z_{c(n)} m_{2(n)}\left(r_{4(n)}\right)^{2}+J_{4(n)}\right] \omega_{4(n)}^{2}\right\} .
\end{gathered}
$$


Or we have

$$
T=\frac{1}{2} \sum_{i=1}^{i=n}\left(J_{11(i)} \omega_{1(i)}^{2}+2 J_{14(i)} \omega_{1(i)} \omega_{4(i)}+J_{44(i)} \omega_{4(i)}^{2}\right)
$$

where

$$
\begin{gathered}
J_{11(i)}=J_{1(i)}+z_{c(i)} J_{2(i)}\left(u_{21(i)}^{(4)}\right)^{2}+\left(J_{3(i)}+J_{7(i)}+\frac{J_{7(i)}^{\prime}+J_{6(i)}}{u_{77(i)}^{2}}\right)\left(u_{31(i)}^{(4)}\right)^{2} ; \\
J_{14(i)}=z_{c(i)} J_{2(i)} u_{24(i)}^{(1)} u_{21(i)}^{(4)}+\left(J_{3(i)}+J_{7(i)}+\frac{J_{7(i)}^{\prime}+J_{6(i)}}{u_{77(i)}^{2}}\right) u_{34(i)}^{(1)} u_{31(i)}^{(4)} ; \\
J_{44(i)}=z_{c(i)} J_{2(i)}\left(u_{24(i)}^{(1)}\right)^{2}+\left(J_{3(i)}+J_{7(i)}+\frac{J_{7(i)}^{\prime}+J_{6(i)}}{u_{77(i)}^{2}}\right)\left(u_{34(i)}^{(1)}\right)^{2}+z_{c(i)} m_{2(i)}\left(r_{4(i)}\right)^{2}+J_{4(i)} .
\end{gathered}
$$

Substituting the expression for the kinetic energy (4) in the Lagrange equation of the second kind (1) and taking the partial derivatives of the angular velocities $\omega_{1}$ and $\omega_{4}$, we obtain a system of two differential equations for each degree

$$
\left\{\begin{array}{l}
J_{11(i)} \dot{\omega}_{1(i)}+J_{14(i)} \dot{\omega}_{4(i)}=M_{361(i)} \\
J_{14(i)} \dot{\omega}_{1(i)}+J_{44(i)} \dot{\omega}_{4(i)}=M_{364(i)}
\end{array}\right.
$$

where $M_{361(i)}=M_{1(i)}+M_{7(i)} u_{71(i)}^{(4)}, M_{364(i)}=-M_{4(i)}+M_{6(i)} u_{74(i)}^{(1)}$.

The consolidated moment $M_{361(i)}$ is determined from the equality of powers of the moments of forces at a fixed carrier, and the moment $M_{364(i)}-$ at a fixed sun gear.

Since the moment $M_{1(i)}=M_{1(i)}\left(\omega_{1(i)}\right)$ is a function of the angular velocity of the sun gears, the moment of change of the load on the drive shaft $M_{4(i)}=M_{4(i)}(t)$ depends on time and $M_{4(i)}=M_{4(i)}(t)$ depends on the fluid flow of the hydraulic system, in the general case the resulting system of equations (5) and (6) is nonlinear.

Consider an example for solving the system of equations (6), when the speed control device will be a two-stage gear differential and closed-loop hydraulic systems, shown in Fig. 2.

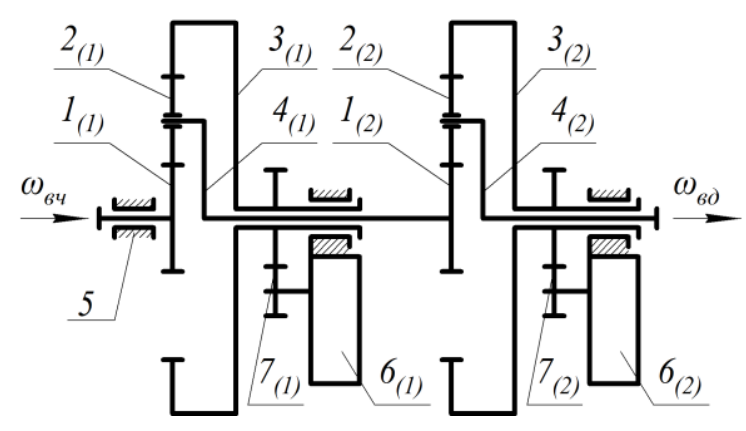

Figure 2. Scheme of two-stage gear differential with closed-loop hydraulic systems with speed control through ring gears

Using (6) we have systems of differential equations of dynamics, respectively for the first (7) and second (8) stages 


$$
\begin{gathered}
\left\{\begin{array}{l}
J_{11(1)} \dot{\omega}_{1(1)}+J_{14(1)} \dot{\omega}_{4(1)}=M_{361(1)} ; \\
J_{14(1)} \dot{\omega}_{1(1)}+J_{44(1)} \dot{\omega}_{4(1)}=M_{364(1)},
\end{array}\right. \\
\left\{\begin{array}{l}
J_{11(2)} \dot{\omega}_{1(2)}+J_{14(2)} \dot{\omega}_{4(2)}=M_{361(2)} ; \\
J_{14(2)} \dot{\omega}_{1(2)}+J_{44(2)} \dot{\omega}_{4(2)}=M_{364(2)}
\end{array}\right.
\end{gathered}
$$

The solution of the system of equations separately for each degree is as follows. We bring equation (7) to the form

$$
\begin{gathered}
a_{1(1)} \dot{\omega}_{1(1)}+b_{1(1)} \dot{\omega}_{4(1)}=c_{1(1)} ; \\
a_{2(1)} \dot{\omega}_{1(1)}+b_{2(1)} \dot{\omega}_{4(1)}=c_{2(1)},
\end{gathered}
$$

where, for the first degree $n=1: a_{1(1)}=J_{11(1)} ; a_{2(1)}=b_{1(1)}=J_{14(1)} ; b_{2(1)}=J_{44(1)} ; c_{1(n)}=M_{361(1)}$; $c_{2(1)}=M_{364(1)}$.

Solve the system of equations (7) for the first degree as follows. Multiply the first equation (9) by $a_{2(1)} / a_{1(1)}$, we obtain

$$
a_{2(1)} \dot{\omega}_{1(1)}+\frac{b_{1(1)} a_{2(1)}}{a_{1(1)}} \dot{\omega}_{4(1)}=\frac{c_{1(1)} a_{2(1)}}{a_{1(1)}} .
$$

Subtract equation (10) from the second equation (9), we obtain

$$
b_{2(1)} \dot{\omega}_{4(1)}-\frac{b_{1(1)} a_{2(1)}}{a_{1(1)}} \dot{\omega}_{4(1)}=c_{2(1)}-\frac{c_{1(1)} a_{2(1)}}{a_{1(1)}} .
$$

In expression (14) we reduce similarities and define $\dot{\omega}_{4(1)}$

$$
\dot{\omega}_{4(1)}=\frac{c_{2(1)} a_{1(1)}-c_{1(1)} a_{2(1)}}{b_{2(1)} a_{1(1)}-b_{1(1)} a_{2(1)}} .
$$

To determine $\dot{\omega}_{1(1)}$, multiply the second equation (9) by $b_{2(1)} / b_{1(1)}$.

$$
\frac{a_{1(1)} b_{2(1)}}{b_{1(1)}} \dot{\omega}_{1(1)}+b_{2(1)} \dot{\omega}_{4(1)}=\frac{c_{1(1)} b_{2(1)}}{b_{1(1)}} .
$$

Next, subtract the first equation (9) from equation (13), we obtain

$$
a_{2(1)} \dot{\omega}_{1(1)}-\frac{a_{1(1)} b_{2(1)}}{b_{1(1)}} \dot{\omega}_{1(1)}=c_{2(1)}-\frac{c_{1(1)} b_{2(1)}}{b_{1(1)}} \text {. }
$$


Then we will reduce similar and define $\dot{\omega}_{1(1)}$.

$$
\dot{\omega}_{1(1)}=\frac{c_{2(1)} b_{1(1)}-c_{1(1)} b_{2(1)}}{b_{1(1)} a_{2(1)}-b_{2(1)} a_{1(1)}} \text {. }
$$

Then for the first stage we have

$$
\dot{\omega}_{1(1)}=\frac{d \omega_{1(1)}}{d t}=\frac{c_{2(1)} b_{1(1)}-c_{1(1)} b_{2(1)}}{b_{1(1)} a_{2(1)}-b_{2(1)} a_{1(1)}} ; \dot{\omega}_{4(1)}=\frac{d \omega_{4(1)}}{d t}=\frac{c_{2(1)} a_{1(1)}-c_{1(1)} a_{2(1)}}{b_{2(1)} a_{1(1)}-b_{1(1)} a_{2(1)}} .
$$
we have:

Similarly, we determine the derivatives of the velocities of the second stage. By analogy

$$
\dot{\omega}_{1(2)}=\frac{d \omega_{1(2)}}{d t}=\frac{c_{2(2)} b_{1(2)}-c_{1(2)} b_{2(2)}}{b_{1(2)} a_{2(2)}-b_{2(2)} a_{1(2)}} ; \dot{\omega}_{4(2)}=\frac{d \omega_{4(2)}}{d t}=\frac{c_{2(2)} a_{1(2)}-c_{1(2)} a_{2(2)}}{b_{2(2)} a_{1(2)}-b_{1(2)} a_{2(2)}} .
$$

Thus, a dynamic mathematical model of the movement of the device links with a multistage gear differential and closed-loop hydraulic systems, with speed control through ring gears, in order to ensure the necessary law of load change on the driven link - the carrier. The obtained dynamic model of a mechanical drive with a multistage gear differential allows to select the necessary hydraulic systems to control the speed of its driven link, and the results can be the basis for quantitative analysis of power dependences of a mechanical drive with hydraulic control.

Conclusions. The built dynamic model of the device of change of speed in mechanical drives of cars allows to analyze and consider the oscillating and shock phenomena in a multistage gear differential from the executive mechanism, besides, allows to make a choice of the necessary closed-loop hydraulic system for control of speed of the conducted link- a carrier.

The obtained results can be the basis for quantitative analysis on the PC of the power dependencies of the mechanical drive with hydraulic control through ring gears, when the load on the driven link - the carrier, changes periodically over time; or the magnitude of the shock load after a sharp increase remains unchanged for a long time; or the magnitude of the shock load after a sharp increase is maintained for a short time; or the actuator stops instantly due to significant overload.

\section{References}

1. Malashchenko V. O., Strilets O. R., Strilets V. M. Klasyfikatsiya sposobiv i prystroyiv keruvannya protsesom zminy shvydkosti u tekhnitsi. Pidyomno-transportna tekhnika. Odesa: ONPU, 2015, no. 1. P. 70-78. [In Ukrainian].

2. Malashchenko, V., Strilets, O., Strilets, V. Determining performance efficiency of the differential in a device for speed change through ring gear. Eastern-European Journal of Enterprise Technologies, 2017, 6 (7 (90)), 51-57. http://dx.doi.org/10.15587/1729-4061.2017.110683

3. Bahk, C.-J, Parker R. G. Analytical investigation of tooth profile modification effects on planetary gear dynamics. Mechanism and Machine Theory, Elsevier, 2013, no. 70. P. $298-319$. https://doi.org/10.1016/j.mechmachtheory.2013.07.018

4. Qilin, H., Yong, W., Zhipu, H., Yudong, X. Nonlinear Dynamic Analysis and Optimization of ClosedForm Planetary Gear System. Mathematical Problems in Engineering, 2013, vol. 2013, 12 p. https://doi.org/10.1155/2013/149046 
5. Salgado, D. R., Castillo, J. M. Analysis of the transmission ratio and efficiency ranges of the four-, five-, and six-link planetary gear trains, Mechanism and Machine Theory, 2014, Vol. 73, pp. 218-243, https://doi.org/10.1016/j.mechmachtheory.2013.11.001

6. Grzegorz, P. Verification Of Gear Dynamic Model In Different Operating Conditions, Scientific Journal of Silesian University of Technology. Series Transport, 2014, 84, 99-104.

7. Fuchun, Y., Jianxiong, F., Hongcai, Zh. Power flow and efficiency analysis of multi-flow planetary gear trains. Mechanism and Machine Theory, 2015, Vol. 92, 86-99. https://doi.org/10.1016/j.mechmachtheory.2015.05.003

8. Pawar1, P. V., Kulkarni, P. R. Design of two stage planetary gear train for high reduction ratio. International Journal of Research in Engineering and Technology, 2015, Vol. 4. Iss. 6, P. 150-157. https://doi.org/10.15623/ijret.2015.0406025

9. Chao, Ch., Jiabin, Ch. Efficiency analysis of two degrees of freedom epicyclic gear transmission and experimental. Mechanism and Machine Theory, 2015, Vol. 87, pp. 115-130. https://doi.org/10.1016/j.mechmachtheory.2014.12.017

10. Tianli, X., Jibin, H., Zengxiong, P., Chunwang, L. Synthesis of seven-speed planetary gear trains for heavyduty commercial vehicle, Mechanism and Machine Theory, 2015, Vol. 90, pp. 230-239. https://doi.org/10.1016/j.mechmachtheory.2014.12.012

11. Drewniak, J., Garlicka, P., Kolber Design for the bi-planetary gear train. Scientific Journal of Silesian University of Technology. Series Transport. 2016, 91, 5-17. https://doi.org/10.20858/sjsutst.2016.91.1

12. Li, J., Hu, Q., Zong, Ch., Zhu, T. Power Analysis and Efficiency Calculation of Multistage Micro-planetary Transmission. Energy Procedia, 2017, 141, 654-659. https://doi.org/10.1016/j.egypro.2017.11.088

13. Wenjian, Y., Huafeng, D. Automatic detection of degenerate planetary gear trains with different degree of freedoms. Applied Mathematical Modelling, 2018, 64, 320-332. https://doi.org/10.1016/j.apm.2018.07.038

14. Esmail, E. L., Pennestrì, E., Hussein Juber A. Power losses in two-degrees-of-freedom planetary gear trains: A critical analysis of Radzimovsky's formulas, Mechanism and Machine Theory, 2018, Vol. 128, 191-204. https://doi.org/10.1016/j.mechmachtheory.2018.05.015

15. Dankov, A. M. Planetary Continuously Adjustable Gear Train With Force Closure Of Planet Gear And Central Gear: From Idea To Design. Science \& Technique, 2018, 17 (3), $228-237$. https://doi.org/10.21122/2227-1031-2018-17-3-228-237

16. Dobariya, M. Design of Compound Planetary Gear Train, International Journal for Research in Applied Science and Engineering Technology, 2018, vol. 6, iss. 4, 3179-3184. https://doi.org/10.22214/ijraset.2018.4527

17. Strilets O. R., Malashchenko V. O., Pasika V. R., Strilets V. M. Dynamichna model keruvannya shvydkosti cherez epitsykl pryvoda iz zubchastoyu dyferentsialnoyu peredacheyu. Visnyk Natsionalnoho universytetu "Lvivska politekhnika". "Dynamika, mitsnist ta proektuvannya mashyn i pryladiv", 2019, no. 911, pp. 63-67. [In Ukrainian].

18. Strilets O. R., Malashchenko V. O., Strilets V. M. Dynamika prystroyu dlya keruvannya zminamy shvydkosti z zubchastoyu dyferentsialnoyu peredacheyu i zamknutoyu hidrosystemoyu cherez sonyachne zubchaste koleso. Visnyk Natsionalnoho tekhnichnoho universytetu "KHPI". Seriya: Mashynoznavstvo ta SAPR, 2020, no. 1'2020. P. 93-98. [In Ukrainian]. https://doi.org/10.33108/visnyk_tntu2020.02.091

19. Strilets O. R., Malashchenko V. O., Strilets V. M. Dynamika prystroyu dlya keruvannya zminamy shvydkosti z zubchastoyu dyferentsialnoyu peredacheyu i zamknutoyu hidrosystemoyu cherez vodylo. Naukovyy visnyk KhDMU, 2020, no. 2 (7), pp. 176-182. [In Ukrainian].

20. Strilets O. R., Malashchenko V. O., Strilets V. M. Vyznachennya zvedenykh obertalnykh momentiv rivnyan dynamiky prystroyiv zminy shvydkosti cherez zubchasti dyferentsialy z zamknutymy hidrosystemamy. Visnyk Khmelnytskoho natsionalnoho universytetu. Naukovyy zhurnal. Tekhnichni nauky, 2020, iss. 4, pp. 18-23. [In Ukrainian].

21. Strilets O. R., Malashchenko V. O., Strilets V. M. Dynamic model of a closed-loop hydraulic system for speed control through gear differential. Scientific Journal of TNTU. Tern.: TNTU, 2020, vol. 98, no. 2. P. 91-98. https://doi.org/10.33108/visnyk_tntu2020.02.091

22. Malashchenko V. O., Strilets O. R., Strilets V. M. Keruvannya shvydkistyu rukhu mashyn bahatostupenevoyu zubchastoyu dyferentsialnoyu peredacheyu cherez epitsykl. Visnyk Natsionalnoho universytetu "L'vivs'ka politekhnika". "Dynamika, mitsnist ta proektuvannya mashyn i pryladiv". 2016. No. 838. P. 57-63. [In Ukrainian].

\section{Список використаної літератури}

1. Малащенко В. О., Стрілець О. Р., Стрілець В. М. Класифікація способів і пристроїв керування процесом зміни швидкості у техніці. Підйомно-транспортна техніка. Одеса: ОНПУ, 2015. № 1. C. $70-78$. 
Dynamic model of speed control through ring gears in a device with a multistage gear differentials and closedloop hydraulic systems

2. Malashchenko, V., Strilets, O., Strilets, V. Determining performance efficiency of the differential in a device for speed change through ring gear. Eastern-European Journal of Enterprise Technologies. 2017. 6 (7 (90)). C. 51-57. http://dx.doi.org/10.15587/1729-4061.2017.110683

3. Bahk, C.-J, Parker R. G. Analytical investigation of tooth profile modification effects on planetary gear dynamics. Mechanism and Machine Theory. Elsevier. 2013. No. 70. P. 298-319. https://doi.org/10.1016/j.mechmachtheory.2013.07.018

4. Qilin, H., Yong, W., Zhipu, H., Yudong, X. Nonlinear Dynamic Analysis and Optimization of Closed-Form Planetary Gear System. Mathematical Problems in Engineering. 2013. Vol. 2013. 12 p. https://doi.org/10.1155/2013/149046

5. Salgado, D. R., Castillo J. M. (2014) Analysis of the transmission ratio and efficiency ranges of the four-, five-, and six-link planetary gear trains, Mechanism and Machine Theory, Vol. 73. P. $218-243$. https://doi.org/10.1016/j.mechmachtheory.2013.11.001

6. Grzegorz Peruń Verification Of Gear Dynamic Model In Different Operating Conditions, Scientific Journal of Silesian University of Technology. Series Transport. 2014. 84, 99-104.

7. Fuchun Yang, Jianxiong Feng, Hongcai Zhang Power flow and efficiency analysis of multi-flow planetary gear trains. Mechanism and Machine Theory. 2015. Vol. 92, 86-99. https://doi.org/10.1016/j.mechmachtheory.2015.05.003

8. Pawar1, P. V., Kulkarni, P. R. Design of two stage planetary gear train for high reduction ratio. International Journal of Research in Engineering and Technology, 2015. Vol. 4. Iss. 6. ESAT Publishing House, Bangalore, India, 150-157. https://doi.org/10.15623/ijret.2015.0406025

9. Chao Chen, Jiabin Chen Efficiency analysis of two degrees of freedom epicyclic gear transmission and experimental. Mechanism and Machine Theory. 2015. Vol. 87, 115-130. https://doi.org/10.1016/j.mechmachtheory.2014.12.017

10. Tianli Xie, Jibin Hu, Zengxiong Peng, Chunwang Liu Synthesis of seven-speed planetary gear trains for heavy-duty commercial vehicle, Mechanism and Machine Theory. 2015. Vol. 90, 230-239. https://doi.org/10.1016/j.mechmachtheory.2014.12.012

11. Drewniak, J., Garlicka, P., Kolber (2016) Design for the bi-planetary gear train. Scientific Journal of Silesian University of Technology. Series Transport. 91, 5-17. https://doi.org/10.20858/sjsutst.2016.91.1

12. Li Jianying, Hu Qingchun, Zong Changfu, Zhu Tianjun Power Analysis and Efficiency Calculation of Multistage Micro-planetary Transmission. Energy Procedia, 2017. 141, 654-659. https://doi.org/10.1016/j.egypro.2017.11.088

13. Wenjian Yang, Huafeng Ding Automatic detection of degenerate planetary gear trains with different degree of freedoms. Applied Mathematical Modelling, 2018, 64, 320-332. https://doi.org/10.1016/j.apm.2018.07.038

14. Esmail, E. L., Pennestrì, E., Hussein Juber A. Power losses in two-degrees-of-freedom planetary gear trains: A critical analysis of Radzimovsky's formulas, Mechanism and Machine Theory, 2018. Vol. 128, pp. 191204. https://doi.org/10.1016/j.mechmachtheory.2018.05.015

15. Dankov, A. M. Planetary Continuously Adjustable Gear Train With Force Closure Of Planet Gear And Central Gear: From Idea To Design. Science \& Technique, 2018. 17 (3), $228-237$. https://doi.org/10.21122/2227-1031-2018-17-3-228-237

16. Dobariya Mahesh Design of Compound Planetary Gear Train, International Journal for Research in Applied Science and Engineering Technology, 2018, vol. 6, iss. 4, 3179-3184. https://doi.org/10.22214/ijraset.2018.4527

17. Стрілець О.Р. Малащенко В. О., Пасіка В.Р., Стрілець В. М. Динамічна модель керування швидкості через епіцикл привода із зубчастою диференціальною передачею. Вісник Національного університету «Львівська політехніка». «Динаміка, міцність та проектування машин і приладів». 2019. № 911. C. 63-67.

18. Стрілець О. Р. Малащенко В. О., Стрілець В. М. Динаміка пристрою для керування змінами швидкості з зубчастою диференціальною передачею і замкнутою гідросистемою через сонячне зубчасте колесо. Вісник Національного технічного університету «ХПІ». Серія: Машинознавство та САПР. 2020. № 1. С. 93-98. https://doi.org/10.33108/visnyk_tntu2020.02.091

19. Стрілець О. Р. Малащенко В. О., Стрілець В. М. Динаміка пристрою для керування змінами швидкості з зубчастою диференціальною передачею і замкнутою гідросистемою через водило. Науковий вісник ХДМУ. 2020. № 2 (7). С. 176-182.

20. Стрілець О. Р. Малащенко В. О., Стрілець В. М. (2020) Визначення зведених обертальних моментів рівнянь динаміки пристроїв зміни швидкості через зубчасті диференціали 3 замкнутими гідросистемами. Вісник Хмельницького національного університету. Науковий журнал. Технічні науки. 2020. Вип. 4. С. 18-23. 
21. Strilets O., Malashchenko V., Strilets V. Dynamic model of a closed-loop hydraulic system for speed control through gear differential. Scientific Journal of TNTU. 2020. Vol 98. No. 2. P. 91-98. https://doi.org/10.33108/visnyk_tntu2020.02.091

22. Малащенко В. О., Стрілець О. Р., Стрілець В. М. (2016) Керування швидкістю руху машин багатоступеневою зубчастою диференціальною передачею через епіцикл. Вісник Національного університету «Львівська політехніка». «Динаміка, міцність та проектування машин і приладів». 2016. № 838. C. 57-63.

\title{
УДК 621.833.65
}

\section{ДИНАМІЧНА МОДЕЛЬ КЕРУВАННЯ ШВИДКІСТЮ У ПРИСТРОЇ 3 БАГАТОСТУПІНЧАСТИМ ЗУБЧАСТИМ ДИФЕРЕНЦІАЛОМ І ЗАМКНУТИМИ ГІДРОСИСТЕМАМИ ЧЕРЕЗ ЕПІЦИКЛИ}

\author{
Олег Стрілець
}

\author{
Наиіональний університет водного господарства та \\ природокористування, Рівне, Україна
}

\begin{abstract}
Резюме. $\quad$ приводах підйомно-транспортних, будівельних, дорожніх, меліоративних, сільськогосподарських і гірничих машин, на автомобілях і тракторах, на судах, літальних $і$ підводних апаратах виникає необхідність керування змінами швидкості за величиною та напрямком їх виконавчих механізмів. Для цього використовуються ступінчасті й безступінчасті коробки швидкостей. Відомі пристрої керування змінами швидкості мають багато недоліків, які негативно впливають на довговічність $i$ надійність деталей приводів $i$ машин у ијілому. Розроблення на рівні винаходів вантажоупорного зупинника у вигляді замкнутої гідросистеми (пат. № 2211796 RU $i$ пат. № 44135 UA) $i$ застосування його у зубчастих диференціалах, дозволило розробити ряд пристроїв для керування змінами швидкості у механічних приводах за рахунок регулювання руху рідини в замкнутій гідросистемі. Це пов'язано з тим, що зубчастий диференціал володіє двома ступенями вільності $і$ в передаванні руху приймає три ланки- сонячне зубчасте колесо, епіцикл $i$ водило. Запропоновано, щяоб одну із ланок використовувати для керування процесом зміни швидкості між ведучою і веденою ланками за допомогою замкнутої гідросистеми. Розроблений на рівні корисних моделей ряд нових пристроїв керування змінами швидкості підвищують роботоздатність техніки, щзо підтверджують проведені теоретичнокомп'ютерні кінематичні та енергетичні дослідження. Розглянуті останні дослідження й публікації присвячені одноступінчастим планетарним і диференціальним зубчастим передачам та мало пов'язані $з$ багатоступінчастими зубчастими диференціалами. Мета даної роботи розробити математичну модель динамічних проиесів у пристроях зміни ивидкості за допомогою багатоступінчастих зубчастих диференціалів з замкнутими гідросистеми у випадку, коли ланками керування є епіцикли, а ведучим валом є сонячне зубчасте колесо першого ступеня, а веденим валом є водило останнього ступеня. Для досягнення мети рух механічної системи у формалізованому вигляді змодельовано рівнянням Лагранжа ІІ роду. Для иього складено вираз для кінетичної енергї ц̆ обертального моменту та отримано систему диференціальних рівнянь, яка виражає математичну динамічну модель пристрою зміни швидкості за допомогою багатоступінчастого зубчастого диференціала з замкнутими гідросистемами через епіцикли. Отримані результати можуть бути підгрунтям для проведення кількісного аналізу на ПК силових залежностей механічного привода з гідросистемним керуванням через епіцикли, коли навантаження, тобто обертальний момент опору на веденій ланиі - водилі, змінюється періодично протягом тривалого часу; або величина ударного навантаження після різкого збільшення залишається незмінним протягом тривалого часу; або величина ударного навантаження після різкого збільшення зберігається протягом малого часу; або виконавчий механізм миттєво зупиняється внаслідок значного перевантаження.
\end{abstract}

Ключові слова: динамічна модель, пристрій для керування змінами швидкості, зубчастий диференціал, замкнута гідросистема, сонячне зубчасте колесо, епіцикл, водило, сателіт. 